\title{
The theory of innovation cycles as a guideline for Mazovia in the fight against recession caused by COVID-19
}

\author{
Michał Klepka
}

\begin{abstract}
The recession triggered by the COVID-19 pandemic is undoubtedly a heavy burden on the developed and driven economy, both in the regional and global context. No one thought that under such unexpected circumstances a global crisis would arise from a place in distant China. From an economic point of view, this fact has stimulated a series of events that have increasingly affected in a larger scope, extent and force the smooth functioning of economic operators. But this situation is not unfamiliar to the economy - it is known that there are business cycles with a confirmed regularity over time. Following this path, the article points out the so-called Kondratiev Waves, which characteristics have elements in common with the current economic situation. Consequently, as in every wave, the phase of recession, caused by some kind of reason, goes through depression to the phase of reconstruction - then the economy gets a significant developmental impulse. The specificity of this time is a large number of innovations, mainly radical and fundamental, but the observations of the economic crises extended over time affect the nature of these innovations.

From the perspective of the lasting pandemic period, that is perhaps impulse in circularity of the economy. We can expect that shipment from recession and depression to recovery should the accumulation of economic potential and the appearance of innovations on the market occur. Mazovia, thanks to innovation specialisations and support for innovative services, may have favourable conditions and a better position at that time.
\end{abstract}

Key words: economic crisis, business cycles, innovations, innovative specialisations of Mazovia, innovative services

\section{A special time for business}

At a time of progressing economic recession, it is difficult to grasp some ideas and realistically forecast the direction of changes in the dynamics of business. What remains is to collect data and analyse how companies behave in particular industries, what factors influence their decisions, how they react to the so-called anti-crisis shields being implemented. Using more advanced forms, we can find out how the deepening crisis affects the maintenance or modification of the created value chains, how the company's resources are used.

In the experts' opinion, the prevailing situation is unprecedented. It is widely commented on in the context of still potential economic consequences - as compared to the economic crises of the 1930s and 1970s. These comparisons are only a point of reference in terms of the conduct of basic development indicators. From a structural point of view, each of them 
occurred in an economy with different levels of technological advancement. This strongly affects the dynamics, scope, depth of the crisis and the ability to seek effective solutions. It is enough to point out that we live in the times of fast and effective communication - using the potential of the Internet, we also share globally created value chains and easily move around the world. These and other features clearly distinguish the beginning crisis from those known only from economic history.

The Internet, and in particular social media - providing an opportunity to quickly create and consult economic information - are rich in examples of changes taking place in the economic space. There are numerous statistical data, collected and verified by modern big data tools. Every day we get to know the current data on COVID-19, information on the implemented anti-crisis procedures appears in the public space. All this causes the current economic crisis, although scientifically it should be defined as a recession, to grow to the scale of a scientific phenomenon. Thanks to the available technologies, the economic history will undoubtedly be enriched with the previously unknown knowledge about the logic of economic crises.

Keeping in mind the ongoing changes and combining it with knowledge of the economic structure, one can try to define the following theses: which logical arrangement of public policy instruments can support the faster emergence of the reconstruction phase? Economic history shows that crises occur in cycles. This is particularly true for Mazovia - the region with the greatest social and economic potential in Poland - where overcoming this challenge becomes crucial. As an active participant in economic life, I can assume that making effective use of the potential of one of the innovative specialisations will be an important element of future development. This will be referred to in the further part of the paper.

\section{The economy entangled in cycle and innovation}

The economic history of the world shows that it is driven by the expectation of continued economic growth. In practice, this growth follows strict rules. The forerunner of this approach was the Russian economist Nikolai Dmyitriyevich Kondratiev, who claimed that the capitalist world moves within regular cycles. At the same time, he is not the only author of the theory on business cycles. Many other deliberations can be found in the literature of the subject. Nevertheless, now more than ever in the history of post-war Poland, Europe and the world, Kondratiev's deliberations have become so obvious and worth quoting.

His historical and economic research, primarily into the level of prices on world markets, but also the level of foreign trade and production, has indicated the existence of long, 50-year economic waves. In the theory of economic thought, this discovery was called Kondratiev Waves theory. One long wave, which in reality lasts from 45 to 60 years, consists of four successive phases: prosperity, recession, depression and recovery. According to the author, the transition between the different phases takes place after each period of reconstruction (Fig. 1). 


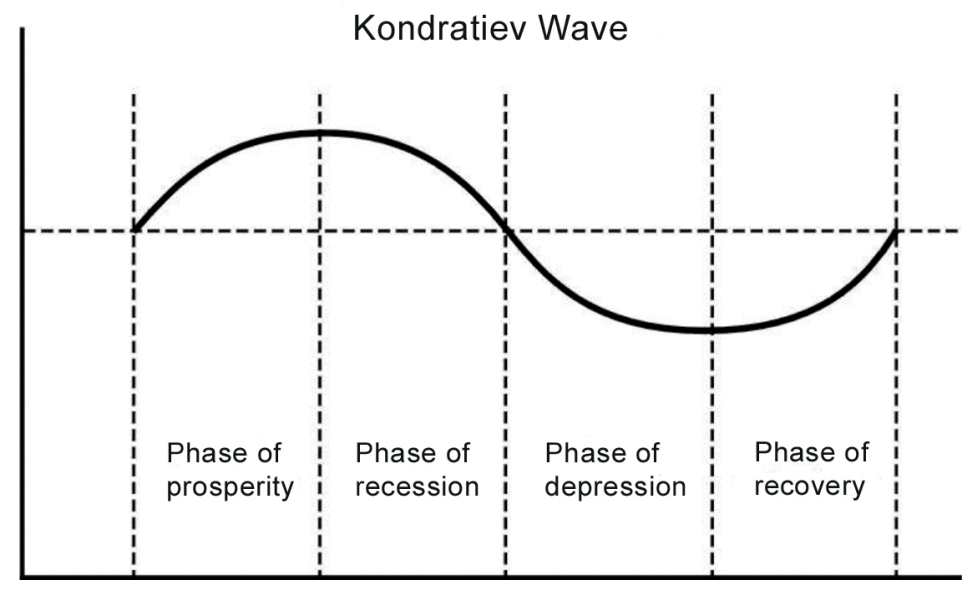

Fig. 1. Kondratiev Wave

Source: J. Sundbo, 1999

In fact, by grouping them, these phases can be divided into two growth phases and the subsequent stagnation phases.

Kondratiev analytically confirmed the existence of 3 waves and derived the estimations by attempting to determine 2 waves in the following system ${ }^{1}$ :

1. Kondratiev Wave: $1780-1845$

2. Kondratiev Wave: $1846-1895$

3. Kondratiev Wave: $1896-1950$

4. Kondratiev Wave: 1951-2000 (estimation)

5. Kondratiev Wave: 2000-? (estimation)

As observed by Rosenberg and Frischtak [1996], Kondratiev's discovery brought a new perspective on the issue of economic growth. It contributed to the creation of two separate directions of research in the history of economic development:

1. the first one, centred around the main criterion of research adopted in constructing Kondratiev's theory, i.e. world trade prices, which directly translated into the interpretation of waves as the results of natural and monetary forces affecting the economy;

2. the second focused on cycles as a phenomenon, understood as a fundamental effect of either the process of capital accumulation ${ }^{2}$ or technological innovation. This direction, with reference to the Kondratiev's theory, suggests a strong relationship between economic cycles and the emergence of innovations. The rest of the paper will concentrate on it as well.

\footnotetext{
${ }^{1}$ Periods and dates assigned to the 4th and 5th Kondratiev cycle should be interpreted as an estimation of the author of the theory. This does not mean a specific year/period, but an approximate moment in economic history when the four phases of the cycle may occur.

${ }^{2}$ This approach was closer to Kondratiev himself, who noted that the material basis of the waves is the appearance, movement and expansion of various capital goods, which require a long period of time and a significant amount of expenditure to produce them.
} 
Kondratiev's deliberations have been repeatedly criticized by economists who questioned the relevance of the applied methodology in the context of disproportions in the development of world economies. ${ }^{3}$ They were also an inspiration to seek new directions in scientific research - one of them is the theory of innovation. Analysing the theory of Kondratiev Waves, one can see a strong connection with the occurrence of innovations. The key is in the nature of these innovations, which due to the extent of the changes they cause, may affect the structures of the economy and, as a result, their passage along the designated path of Waves. This approach assumes in part a non-economic dimension of the Waves, resulting from defined price levels in trade. Consequently, the theories about the existence of noneconomic determinants of economic growth can be drawn.

Pointing to innovation processes was widely supported, and at the same time became an inspiration to many theorists - authors of later concepts of the innovation process. The existence and theoretical correctness of Kondratiev Waves have been the subject of numerous analyses and deliberations, which are represented by the work of such economists as Chr. Freeman [1984], J. Schumpeter, G. Mensch or S. Kusnetz.

By verifying the relationship between economic waves and innovation, it can be concluded that innovations appear in cycles. Kondratiev associated this with the cyclicality of capital accumulation in the depression phase. This phase, in his opinion, is a period in which economies are being cleaned of elements that, for various reasons, did not function in harmony and did not contribute to preparing the whole system for a new period of growth. It is a period of radical innovation, during which technologies from the completed growth period become cheaper and more common. As a result, industry consolidates around radical innovations that narrow profits and overall growth.

The author pointed out that the long-term growth phase is caused by the accumulation of innovations in the depression phase and their introduction in the recovery phase. The advocate of this approach was Joseph Schumpeter, the father of the theory of innovation. He made modifications to the theory of waves resulting from technological development and progress. Having an educated view on innovation, he was able to relate directly to how cycles are formed. In a synthetic sense, his approach indicates that waves are created by concentrating on basic innovations, which in turn lead to technical revolutions and affect the development of new production sectors. His classic approach sees innovations in innovative

${ }^{3}$ This direction met with numerous controversies, which to a large extent were concentrated around:

- the way the author defined economic waves, i.e. based on emerging differences in world price levels. This led to criticism of the ability to assess the factors influencing economic cycles in the long term and the possibility of empirically examining these processes through indicators,

- the possibility of reflecting economic cycles at the global level in a situation where the economies of individual countries display differences in the level of development and industrialisation. This, in turn, affects the processes that form economic cycles,

- the way of defining cycles as the results of the impact of the internal forces of economies, rather than the external conditions in which these economies operate. The main academic opponent in this respect was D.I. Oparin.

The main opponents of the Kondratiev Cycles theory were Friedrich August von Hayek and Ludwig Heinrich Edler von Mises - representatives of the Austrian economic school. 
products, services and production methods, opening up new markets and sources of raw materials, as well as alternative forms of business organisation. Kondratiev Waves in this sense are caused by the demand for solving new problems and delivering these solutions by innovative companies. Therefore, it can be indicated that each wave has its own - individual innovative character.

The period in which Schumpeter lived was characterised by a far less dynamic innovation process than today. The level of penetration of particular areas of life and economic activity was much lower. Even then he noticed that pioneers introducing innovations in one branch of production removed obstacles existing in other branches and that innovations in one branch would stimulate changes in another. This accumulation was linked to the discontinuity of the development process by stating that 'innovations are not isolated events (...), they tend to group, occur collectively (...), are at no point in time spread throughout the economic system, but rather concentrate on certain sectors and their environment'. [Kwiatkowski 1990, pp. 21-22]. This idea served the author in formulating the reasons for the occurrence of economic crises - in the discontinuity of innovations and tendencies to group in certain periods and places. ${ }^{4}$

The scientific interpretation of innovation cycles derived from Kondratiev's theory found support in the work of Jon Sundbo [1999], who pointed at J.J. van Duijn as an inspiration for his theses definition. The scientist focused his attention on the theory of innovation and indicated that each of Kondratiev Waves, and consequently each period of growth of particular cycles, has its approach towards innovation and creates its models of the innovation system. The discovery that the theory of innovation is a reflection of the economic processes taking place in the two indicated phases, which differ in various cycles, contributed to Sundbo's model of the shifted phases of KondratievWaves. Thus, each of them begins with economic development and growth. In reality, he shifted one phase back from the original version presented by Kondratiev. In this way, the defined waves now indicate the transition between particular phases after each period of depression. In doing so, these cycles point to the natural process of creating innovations and knowledge in the 'recovery' phase, and using and spreading them in the 'prosperity ${ }^{\prime 5}$ phase. The arrangement of the waves defined in this way is as follows (Fig. 2):

1. Kondratiev Wave: $1770-1836$

2. Kondratiev Wave: $1836-1883$

3. Kondratiev Wave: 1883-1937

4. Kondratiev Wave: 1937-1983

5. Kondratiev Wave: 1983-?

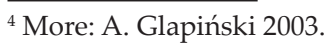

${ }^{5}$ This theory is included in: Fluctuations in Innovations over Time [in:] Chr. Freeman 1984. 


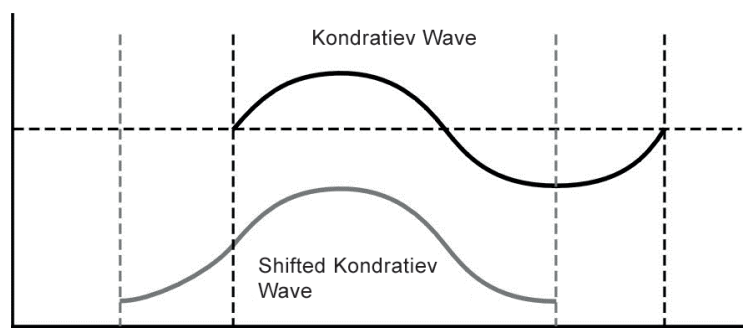

Fig. 2. Kondratiev Wave and Shifted Kondratiev Wave

Source: J. Sundbo, 1999

It should be emphasized that the existence of five defined Kondratiev Waves is not equivalent to the existence of five periods in which the concepts of innovation were developed. The available knowledge in this area indicates the emergence of the first analyses of the innovation process at the beginning of the third wave, i.e. at the end of the 19th century. The mere existence of the waves is not proof of the existence of different ways of understanding innovation processes. This was a direct consequence of the changing economic world. Over the years, counting from the beginning of the third shifted Kondratiev Wave, i.e. since 1883, the economy has developed intensively, which led to the creation of more technologically advanced sectors. As a result, the global economy, although only a few countries can be considered as such, became more and more technologically saturated, and further innovations required the generation of more and more advanced forms of activity. Such a functioning reality, in which innovations were generated, was reflected in the numerous social and economic theories of the contemporary theoreticians, including Schumpeter.

\section{History is being shaped today}

The deliberations on Kondratiev long-term economic Waves, despite the doubts indicated earlier, are the source of a new thesis. It specifies the cyclical effect on the current global economic situation. The justification lies in the results of the scientist's estimations, which led to the assumption of the beginning of the 5th Wave at the turn of the century, which Jon Sundbo - shifting the Wave one phase back - estimated for 1983.

Following the logic of Sundbo's deliberations, one might put forward a thesis that the current economic recession is in line with the predicted wave scenario. The question of the role of the financial crisis caused by the collapse of the global financial system in 2007-2009 should also be addressed. The state of the world economy in the last decade is another issue whether the dynamics of change, driven by enormous efforts, lack of access to raw materials, mainly human resources and a huge burden on the environment, were a testimony to the ongoing prosperity, or a specific crisis - characteristic of this wave?

The fact is that the global economy has fallen into recession. We are facing shrinking production capacity, broken value/supply chains, but above all restrictions on people who are 
both productive resources and consumers of goods and services at the same time. Without them, the economic cycle cannot be closed. This further weakens the administration's ability to redistribute profits - due to their systematic dwindling.

So the economic history is being written today. In a dozen or so years, our knowledge of the causes, course and consequences will be very extensive and detailed. But can we draw conclusions from the previous crises today? These will help us to model economic processes and guide the economy towards recovery? ${ }^{6}$

The interviews conducted with small, medium and large businesses in Mazovia show that the key issue is to return to the freedoms from before the pandemic. ${ }^{7}$ This is mainly the reason why we fell into recession. Entrepreneurs from the surveyed industries ${ }^{8}$ unanimously confirm that the current economic recession is characterized by a general fall in people's trust towards each other and fear of the disease. This generates specific consumer behaviour. While freeing up the market is a desirable state, there is no question of restoring pre-pandemic market processes. It is difficult to make an unambiguous - even a general diagnosis, as the variety of situations will be exceptionally great. The entrepreneurs indicated several scenarios awaiting the companies:

- in B2C industries, there will have to be a remodelling of the business, the introduction of new sales tools, but most importantly, guaranteeing a redefined value for the customer, which is the security of purchase,

- $\quad$ B2B industries and companies will have to break their value chains and lose either contractors or suppliers, depending on the company,

- production companies and industries will face a drop in sales, which will force them to reduce costs and redirect their resources to activities that will guarantee their liquidity,

- companies using the so-called working capital loans must take into account the risk of losing financial liquidity and the necessity to renegotiate the terms of loan agreements with financial institutions,

- companies operating in the tourism industry will have to re-model their offer, directing it to higher-value services in return for the current occupancy rate (KPI).

The discussion with entrepreneurs leads us to the conclusion that the assessment of enterprise sector condition still requires several months - counting from the beginning of the pandemic in Poland (prediction at the end of 2021). This indicates the necessity to complete one whole season in the new economic conditions. Only then will the new conditions of business activity be known: level of prosperity, consumer behaviour, trade indicators, etc.

\footnotetext{
${ }^{6}$ While looking for arguments to thesis on the consequences of the recession for the world economy in the current 6th Kondratiev Wave (provided that the data collected and analysed for several decades confirm this) it is worth to notice the theory of the German expert Leo Nefiodov. He conducted analytical work on the cycle and presented in the article The Sixth Kondratieff - The New Long Wave of the Global Economy in 2014. More: https://www.sociostudies.org/upload/sociostudies.org/almanac/k_waves_3/203-209.pdf

${ }^{7}$ From March to May 2020, 12 interviews were conducted with companies from the Mazovian region and 10 interviews with representatives of institutions supporting business.

${ }^{8}$ Among others, tourism, commerce, IT, 3D printing, automotive services, event industry.
} 
The entrepreneurs agree with the general observation that a new economic history is being written and what is now a reality for entrepreneurs will be a practical knowledge in the future - although if Kondratiev and Sundbo's theory about the accumulation of development capital and explosion of basic innovations in the revival phase is realised, the next economic crisis may turn out to be completely different from the current one. After all, compared to the 1980s, the starting point is very different.

Historically, economic crises have been caused by the emergence of global factors. Each time there were factors influencing access to productive resources, although the logic was behind economic factors. The current recession and the anticipated crisis caused by the virus, a non-economic stimulus ${ }^{9}$, has again strongly affected access to a variety of resources, but above all restricted the market for products and services. A thorough understanding of the physiology of the crisis will require several scientific works and analyses. This confirms the thesis, already defined by Kondratiev, on this socio-economic phenomenon.

\section{Mazovia on the road to recovery}

The uncertainty of tomorrow is the only sure thing in today's business reality. And although this is an unprecedented situation in the history of the vast majority of companies in Poland ${ }^{10}$, it is possible to try to take actions that will create conditions to fight the crisis. First of all, the regional authorities, who can adapt with greater precision to the needs of entrepreneurs suffering from the crisis. As opposed to general support mechanisms created at the government level.

The public support is characterised by the fact that the closer the support mechanisms are defined to businesses; the more data is needed. With the crisis just beginning to unfold, there is a general lack of data to which reference can be made. Historical data are no longer reliable, although they do help to understand what potential lies in the economy. With this in mind, attempts can be made to diagnose and look for trends in the variables that characterise negative changes in the region's economy and to estimate in what economic processes a deficiency will occur, and in what one can expect to maintain or even develop. An important tool in the analyses may be the verification of historical support granted e.g. from the Structural Funds, in particular for the creation of innovative potential of companies.

Transferring the deliberations to the Mazovian Voivodeship, it is worth noting that the objectively selected structure of innovative specialisations designated for the needs of the implementation of the Structural Funds was the strong point of the development policy - in the section on making the economy more innovative. ${ }^{11}$ The consistently undertaken policy

\footnotetext{
${ }^{9}$ In this context, numerous speculations by representatives of business circles and others sound interesting.

${ }^{10}$ Koźmiński University conducted research on family businesses in Poland, where it collected information on dozens of companies with a long, even 100 years of tradition. Therefore, it should be assumed that they met with the phenomenon of economic crisis.

${ }^{11}$ The specialisations have been defined in the Regional Innovation Strategy of the Mazovian Voivodeship until 2020, these are: safe food, intelligent management systems, modern business services, high quality of life.
} 
provided the specialisations with a set of dedicated forms of support, contributing to their integrated development.

Particular attention should be paid to the fact that in the implementation of the policy the regional authorities identified the value chains associated with specialisations. The list includes traditional industries (e.g. horticulture, meat production), and hi-tech (energy efficiency, telemedicine, photonics, automation and robotics, space industry) [Report of the EMU 2019, p. 8].

The very fact that the region's authorities have turned their attention to the established value chains is an important step in creating future support policies. As has been noted by entrepreneurs, broken value chains will be the key issue of the economic recession, as well as of course market access.

Directing research funding towards supporting innovative specialisations has also been an important element of the current policy. Thus, public intervention in the field of R\&D projects was narrowed down to the most promising subjects, the implementation and commercial use of which is expected to significantly contribute to the economic and innovative development of the region [EMU 2018].

Having in mind the previously quoted opinions of entrepreneurs ${ }^{12}$, two specialisations reach exceptional importance. They combine the potential of services related to a business organization: intelligent management systems and modern business services. The first case focuses on technological solutions enabling optimisation and automation of production processes (including manufacturing techniques), monitoring and infrastructure control. The second specialisation included solutions for the development of the market of business support services and improvement of the business environment. Effectively the region invested in the development of competences of both service companies and business support institutions in 2014-2020. This is an important area for the current economic situation. Regional analyses show that many companies have improved their logistics and ecology management skills. The priority directions of research should focus on tools for intelligent management systems. A focus on counteracting threats in the work environment and risk management was observed as part of the activity of companies. ${ }^{13}$

The MSODI project - implemented by the Marshal's Office of the Mazovian Voivodeship - is an important tool of Mazovia's policy. It aims to create new development services stimulating innovation in companies. The region still has untapped potential to create services directly responding to the problems of companies during the recession. The business support institutions in the region can obtain financial support for conceptual work, implementation and piloting of new services. Addressing the situation of companies plays a key role in this process, and the way and scope of services provided should benefit companies in the form of innovation. The conducted interviews confirm great interest in maintaining the current di-

\footnotetext{
${ }^{12}$ In particular, statements related to the impact of the crisis on the maintenance of value chains and the potential need to redefine the way resources are being used.

${ }^{13}$ More: Priorytetowe kierunki badań w ramach inteligentnej specjalizacji województwa mazowieckiego, 2018 and Przeglad Inteligentnej Specjalizacji Województwa Mazowieckiego, 2019.
} 
rection of supporting the innovativeness of the Mazovian Voivodeship. They also anticipate introducing solutions allowing for more effective use of IT technologies in running a business. COVID-19 has disturbed many business processes, using the advantages of stimulating specialisation has become valuable.

To reach conclusions, the achievements of innovative specialisations and the possibility to create new services create favourable conditions in a situation of deepening recession. This potential should be managed skill fully, but most importantly, the situation of companies should be monitored - directly and through involvement and communication with institutions in their environment.

Stakes are high, apart from the impact on the negative effects of the recession - which from the perspective of the regional authorities is a key objective - Mazovia may contribute to the process of rebuilding the Polish economy. Recalling the results of Sundbo's work on economic cycles - this may mean participation in the implementation of innovations that are key to the transition to the development phases characteristic for the period of prosperity. The entrepreneurs believe that the companies in Mazovia (and not only) hold production capacities and material and non-material resources. They can join supply chains and sometimes become their important links. Therefore, one can put forward a thesis that advanced organisational solutions, including newly created and managed value chains, marketing innovations and a strong orientation towards pro-ecological solutions will prove to be a potential source of innovations characteristic for the progressing crisis.14 In such a scenario, Mazovia may gain an advantage - by combining the potential of the above-mentioned specialisations, new business services and the unique potential of the region's economic sphere. The positive scenario assumes that companies from Mazovia should flood the market with ideas, but what is important, they should focus on creating local value chains - there is enough potential for that. The strengthening effect can also be achieved through the new Structural Funds perspective, which when well-programmed can be a catalyst for accelerating such a scenario.

Institutions supporting business count on maintaining the direction of specialisation development in the Mazovian Voivodeship. Their involvement in stimulating innovation has been very active, many institutions have taken actions to expand their competences and introduce new pro-innovation services on the market.

\section{References}

Freeman Chr., 1984, Long Waves in the World Economy, An Elgar Reference Collection, London. Glapiński A., 2003, Teoria cyklu koniunkturalnego J.A. Schumpetera, Studia i Prace Kolegium Zarządzania i Finansów, Szkoła Główna Handlowa, 34, pp. 138-160.

${ }^{14}$ It is worth mentioning that the introduction of business management techniques was an important innovation in the 1950s. 
Kwiatkowski S., 1990, Społeczeństwo innowacyjne, Państwowe Wydawnictwo Naukowe, Warszawa.

Nefiodow L., 2014, The Sixth Kondratieff - The New Long Wave of the Global Economy, Social Studies, https://www.sociostudies.org/almanac/articles/the_sixth_kondratieff_-_the_new_ long_wave_of_the_global_economy/.

Priorytetowe kierunki badań w ramach inteligentnej specjalizacji województwa mazowieckiego, 2018, Urząd Marszałkowski Województwa Mazowieckiego, Warszawa.

Raport UMWM, 2019, Przegląd Inteligentnej Specjalizacji Województwa Mazowieckiego, Urząd Marszałkowski Województwa Mazowieckiego, Warszawa.

Sundbo J., 1999, The Theory of Innovation, Entrepreneurs, Technology and Strategy, Edward Elgar Publishing, United Kingdom.

Rosenberg N. I., Frischtak C. R, 1996, Technological innovation and long waves [in:] Chr. Freeman (ed.), Long Wave Theory, An Elgar Reference Collection, United Kingdom. 


\section{Teoria cykli innowacji wskazówką dla Mazowsza w walce z recesją wywołaną COVID-19}

\section{STRESZCZENIE}

Recesja wywołana pandemią COVID-19 jest niewątpliwie dużym obciążeniem dla rozwiniętej i napędzonej gospodarki, zarówno w kontekście regionalnym jak i globalnym. Nikt nie spodziewał się, iż w tak nieoczekiwanych okolicznościach z jednego miejsca w odległych Chinach wywoła się ogólnoświatową recesję. Z ekonomicznego punktu widzenia fakt ten stał się bodźcem do łańcucha zdarzeń, które w coraz większym obszarze, zakresie i sile oddziaływały na sprawne funkcjonowanie podmiotów gospodarczych. Ale sytuacja ta nie jest ekonomii obca - wiadomo bowiem o istnieniu cykli koniunkturalnych o potwierdzonej regularności w czasie. Idąc tym tropem, $\mathrm{w}$ artykule zwrócono uwagę na tzw. Cykle Kondratiewa, których cechy mają elementy wspólne z obecną sytuacją gospodarczą na świecie. Konsekwentnie, jak w każdym cyklu, faza recesji wywołana jakimś bodźcem, przechodzi przez depresję do fazy odbudowy - wówczas gospodarka dostaje istotnego impulsu rozwojowego. Specyfika tego czasu to duża liczba innowacji, głównie radykalnych i podstawowych, jednakże obserwacje rozciagniętych w czasie kryzysów gospodarczych oddziałują na charakter tych innowacji.

Z perspektywy panującej sytuacji pandemicznej można postawić tezę, iż jest ona czynnikiem kształtującym cykliczność - wywołała recesję - co w dłuższej perspektywie sprzyjać będzie nagromadzaniu potencjału gospodarczego i pojawiania się innowacji na rynku. Mazowsze, dzięki specjalizacjom innowacyjnym i wspieraniu innowacyjnych usług, może tworzyć sprzyjające warunki do obrony przed negatywnym oddziaływaniem recesji i szybsze przejście do fazy trwałego wzrostu gospodarczego.

Słowa kluczowe: kryzys gospodarczy, cykle koniunkturalne, innowacje, specjalizacje innowacyjne Mazowsza, innowacyjne usługi

Michat Klepka, PhD Eng, lecturer at Warsaw School of Economics at The Collegium of Business Administration, Director of the Urban Policy and Innovation Department in Mazovia Development Agency. Expert and advisor of regional governments on the development policy management and building innovation ecosystems. Active entrepreneur and manager with experience in commercialisation, owner of an industrial design and a few trademarks. Educator of children and youth.

Michał Klepka, dr inż., wykładowca Szkoły Głównej Handlowej w Warszawie w Kolegium Nauk o Przedsiębiorstwie, Dyrektor Działu Polityki Miejskiej i Innowacyjności w Agencji Rozwoju Mazowsza. Wieloletni ekspert i doradca samorzq̨dów zarządzania polityką rozwoju i budowania ekosystemów innowacji. Aktywny przedsiębiorca i menadżer z doświadczeniem w komercjalizacji wyników badań naukowych, właściciel wzoru przemysłowego i kilku znaków towarowych. Edukator dzieci i młodzieży. 